\title{
CXCL2 Gene
}

National Cancer Institute

\section{Source}

National Cancer Institute. CXCL2 Gene. NCI Thesaurus. Code C18426.

This gene is involved in the regulation of angiogenesis. 